\title{
Effects of ocean acidification on marine ecosystems
}

\author{
Idea: Howard I. Browman \\ Coordination: Alain F. Vézina, Ove Hoegh-Guldberg
}

\section{CONTENTS}

Vézina AF, Hoegh-Guldberg $O$

Introduction

$199-201$

Pörtner HO

Ecosystem effects of ocean acidification in

times of ocean warming: a physiologist's view ..... 203-217

Hofmann GE, O'Donnell MJ, Todgham AE

Using functional genomics to explore the

effects of ocean acidification on calcifying

marine organisms

Rost B, Zondervan I, Wolf-Gladrow D

Sensitivity of phytoplankton to future changes

in ocean carbonate chemistry: current knowledge,

contradictions and research directions

Balch WM, Fabry VJ

Ocean acidification: documenting its impact on calcifying phytoplankton at basin scales

Atkinson MJ, Cuet P

Possible effects of ocean acidification on coral reef biogeochemistry: topics for research

\section{Lough JM}

Coral calcification from skeletal records

revisited $257-264$

Andersson AJ, Mackenzie FT, Bates NR

Life on the margin: implications of ocean acidification on Mg-calcite, high latitude and cold-water marine calcifiers $265-273$

Kurihara $\mathbf{H}$

Effects of $\mathrm{CO}_{2}$-driven ocean acidification on the early developmental stages of invertebrates ... 275-284

Dupont S, Havenhand J, Thorndyke W,

Peck L, Thorndyke $M$

Near-future level of $\mathrm{CO}_{2}$-driven ocean acidification radically affects larval survival and development in the brittlestar Ophiothrix fragilis ... 285-294

Ishimatsu A, Hayashi M, Kikkawa T

Fishes in high- $\mathrm{CO}_{2}$, acidified oceans $295-302$

Gutowska MA, Pörtner HO, Melzner F

Growth and calcification in the cephalopod

Sepia officinalis under elevated seawater $\mathrm{pCO}_{2} \ldots \ldots$ 303-309

\section{Introduction}

\author{
Alain F. Vézina ${ }^{1, *}$, Ove Hoegh-Guldberg ${ }^{2}$ \\ ${ }^{1}$ Bedford Institute of Oceanography, 1 Challenger Drive, Dartmouth, Nova Scotia B2Y 4A2, Canada \\ ${ }^{2}$ Centre for Marine Studies, The University of Queensland, St. Lucia, Queensland 4067, Australia
}

Although the potential for increased atmospheric $\mathrm{CO}_{2}$ concentrations to affect ocean $\mathrm{pH}$ and marine calcification rates has been known for decades, the issue came to the fore following the Ocean in a High $\mathrm{CO}_{2}$ World symposium (Orr et al. 2005a). Ocean acidification has recently been the subject of several high-profile publications (Caldeira \& Wickett 2003, Orr et al. 2005b), comprehensive priority-setting assessments (Royal Society 2005,
Kleypas et al. 2006), and numerous articles in the mass media. Despite the serious implications of ocean acidification for marine ecosystems, thorough scientific investigation of this problem is only just beginning.

It is accepted that average global ocean $\mathrm{pH}$ has declined over the 20th century and will continue to do so within the near future (Caldeira \& Wickett 2005). It is also generally accepted that the $\mathrm{pH}$ in the global 
ocean has already fallen by 0.1 units and is likely to fall a further 0.3 units by 2050 and 0.5 units by 2100 (Caldeira \& Wickett 2005). These predictions are relatively certain, in part because the geological feedbacks that could affect the decline in $\mathrm{pH}$ are too slow to have any real effect on a century timescale. The potential effects of this decline in $\mathrm{pH}$, however, on marine organisms and ecosystems are poorly understood. We felt that it was worthwhile at this early stage to assemble articles that critically evaluate the current state of knowledge on this topic and make constructive suggestions for future research.

Past work on the biological effects of change in ocean $\mathrm{pH}$ has focused on acute exposure, rather than on slow and continuous decline in $\mathrm{pH}$ levels such as those expected under global climate change. Without an understanding of how such a slow and continuous decline in $\mathrm{pH}$ is likely to affect ocean ecosystems, we may miss important aspects of this global ocean $\mathrm{pH}$ change. To compound this uncertainty, recent research (Iglesias-Rodriguez et al. 2008, Gutowska et al. 2008, this Theme Section [TS]) reveals counter-intuitive, positive/neutral effects of acidification on some organisms and processes. These studies highlight a near universal issue arising in studies of broad environmental problems: that is, the diversity and complexity of responses by organisms make it difficult to form general predictions.

Faced with this complexity, the first article in this TS proposes a bold program which focuses on unraveling the fundamental physiological processes that underpin the diversity of observed responses (Pörtner 2008, this TS). The proposal for a focus on physiology will not necessarily meet with universal agreement; nevertheless, a deeper understanding of ocean acidification at a physiological level is essential for progress in understanding impacts that extend beyond the effects on calcification. It is also stimulating to reflect on potential unifying principles that may underlie organisms' responses to temperature, $\mathrm{CO}_{2}$ and oxygen, and thus affect community structure. This approach already leads to the inference that higher invertebrates and other organisms with high metabolism and well-developed acid/base regulation may withstand acidification better than the lower invertebrates (see Ishimatsu et al. 2008, this TS, Gutowska et al. 2008).

Using functional genomics is another way to derive an increased mechanistic understanding of responses to acidification. This in turn can lead to more general understandings as outlined by Hofmann et al. (2008, this TS). Although the focus of their paper is on laboratory studies of biomineralization, the approach could be applied to other potential physiological responses and could lead to diagnostic tools that can be used in the field (DeLong \& Karl 2005).
Rost et al. (2008, this TS) review the methodologies that have been used to date to investigate effects of $\mathrm{pH}$ on phytoplankton. They report that differences in experimental design and methods may underlie the sometimes contradictory results. Importantly, these authors provide a framework for future experimental studies that may help eliminate these problems. Shifting from the laboratory to the field, Balch \& Fabry (2008, this TS) review current approaches to estimate changes in pelagic calcification in situ and propose a program to quantify the effects of acidification on calcification on the global scale.

Most of the research to date on the effects of ocean acidification has focused on calcifying organisms, in particular structure-forming organisms such as corals. The rise of $\mathrm{CO}_{2}$ in ocean waters leads to more corrosive conditions for calcifying organisms, making it more difficult for them to build and maintain their carbonate skeletons. Also, the threatened status and ecological importance of coral reefs inevitably brings attention to their responses to acidification. It is widely recognized that the saturation state of carbonates has a major influence on calcification at species and community levels (Kleypas \& Langdon 2006). Atkinson \& Cuet (2008, this TS), however, point out a number of biological and ecological factors that can influence this relationship and propose a research program to address the uncertainties. Lough (2008, this TS) discusses the recent shift from growth-based indicators towards geochemical indicators of coral response to environmental conditions, and makes the point that growth records remain a rich source of information and should not be forgotten in the continuing investigation of coral response to acidification and temperature changes. Andersson et al. (2008, this TS) combine a review of extant knowledge and model calculations to predict faster than expected changes in community structure, particularly at high latitudes, linked mainly to the differences in solubility among different forms of carbonate skeletons. These papers together illustrate that much remains to be done, even in the best-studied part of the acidification puzzle.

Comparatively little attention has been devoted to the impact of acidification on other ecosystem components and processes. A critical question here is the potential effect of acidification on early life stages of marine invertebrates. These larval and juvenile stages may be particularly sensitive, in part because they form their internal skeletons out of amorphous calcite which is more soluble than other forms of carbonate. Kurihara (2008, this TS) reviews the current state of knowledge on the effects of acidification on the reproduction and early life stages of marine invertebrates, to reveal just how little we know about this crucial issue, and to sketch a way forward. Dupont et al. (2008, 
this TS) offer disquieting evidence that populations of a major keystone species of the North Atlantic may be severely disrupted through the effects of probable future acidification levels on its larval stages. The impact of ocean acidification on marine fish is reviewed by Ishimatsu et al. (2008) who identify the scarcity of studies using realistic $\mathrm{pH}$ levels under conditions of prolonged exposure, and urge new research along these lines. The TS closes with a paper by Gutowska et al. (2008) which reports counter-intuitive responses of a cephalopod species to very high $\mathrm{CO}_{2}$ levels, neatly illustrating the deep uncertainties within this major environmental issue.

This TS covers a broad range of issues, approaches and taxonomic groups, but there were certainly areas we were not able to cover. Many authors discuss the potential for genetic adaptation to rapid ocean acidification, and this remains a topic of great importance; however, little progress has been made in this path of research. There are few analyses based on evolutionary thinking (although the study of Collins \& Bell 2004 is often cited). Another gap is the integration of the information into models that can help us apprehend higher levels (community, ecosystem) responses to acidification. There is still uncertainty as to what types of models and modeling studies are needed to integrate extant knowledge and extrapolate possible future states of the ecosystem; whether it is just a question of adding incrementally to the existing ecologicalbiogeochemical models used extensively for global change research (Hood et al. 2006), or whether we need new approaches or different model structures. Interestingly, these are also gaps that were identified in the recent reports to the Royal Society and US funding agencies (Royal Society 2005, Kleypas et al. 2006). Hopefully, the next reviews and syntheses of this rapidly evolving field will include more work in these critical areas.

Acknowledgements. Special thanks are due to Howard Browman who came up with the original idea for this TS, helped launch the process and participated actively in the coordination and editing in the early phases. This would not have happened without his foresight and leadership. We thank the authors and over 45 reviewers who were willing to participate and made this TS possible.

\section{LITERATURE CITED}

Andersson AJ, Mackenzie FT, Bates NR (2008) Life on the margin: implications of ocean acidification on $\mathrm{Mg}$-calcite, high latitude and cold-water marine calcifiers. Mar Ecol Prog Ser 373:265-273

Atkinson MJ, Cuet P (2008) Possible effects of ocean acidification on coral reef biogeochemistry: topics for research. Mar Ecol Prog Ser 373:249-256
Balch WM, Fabry VJ (2008) Ocean acidification: documenting its impact on calcifying phytoplankton at basin scales. Mar Ecol Prog Ser 373:239-247

Caldeira K, Wickett ME (2003) Anthropogenic carbon and ocean pH. Nature 425:365-365

Caldeira K, Wickett ME (2005) Ocean model predictions of chemistry changes from carbon dioxide emissions to the atmosphere and ocean. J Geophys Res 110, C09S04, doi: 10.1029/JC002671

Collins S, Bell G (2004) Phenotypic consequences of 1,000 generations of selection at elevated $\mathrm{CO}_{2}$ in a green alga. Nature 431:566-569

DeLong EF, Karl DM (2005) Genomic perspectives in microbial oceanography. Nature 437:336-342

Dupont S, Havenhand J, Thorndyke W, Peck L, Thorndyke M (2008) Near-future level of $\mathrm{CO}_{2}$-driven ocean acidification radically affects larval survival and development in the brittlestar Ophiothrix fragilis. Mar Ecol Prog Ser 373: 285-294

Gutowska MA, Pörtner HO, Melzner F (2008) Growth and calcification in the cephalopod Sepia officinalis under elevated seawater $\mathrm{pCO}_{2}$. Mar Ecol Prog Ser 373:303-309

Hofmann GE, O'Donnell MJ, Todgham AE (2008) Using functional genomics to explore the effects of ocean acidification on calcifying marine organisms. Mar Ecol Prog Ser 373:219-225

> Hood RR, Laws EA, Armstrong RA, Bates NR and others (2006) Pelagic functional group modeling: progress, challenges and prospects. Deep-Sea Res II 53:459-512

Iglesias-Rodriguez MD, Halloran PR, Rickaby REM, Hall IR and others (2008) Phytoplankton calcification in a high$\mathrm{CO}_{2}$ world. Science 320:336-340

Ishimatsu A, Hayashi M, Kikkawa T (2008) Fishes in high$\mathrm{CO}_{2}$, acidified oceans. Mar Ecol Prog Ser 373:295-302

Kleypas JA, Langdon C (2006) Coral reefs and changing seawater chemistry. In: Phinney JT, Hoegh-Guldberg O, Kleypas J, Skirving W, Strong A (eds) Coral reefs and climate change: science and management. AGU Monograph Series, Coast Estuar Stud 61:73-110

Kleypas JA, Feely RA, Fabry VJ, Langdon C, Sabine CL, Robbins LL (2006) Impacts of ocean acidification on coral reefs and other marine calcifiers: a guide for future research. Report of a workshop held 18-20 April 2005, St. Petersburg, FL, sponsored by NSF, NOAA, and the US Geological Survey

Kurihara $\mathrm{H}$ (2008) Effects of $\mathrm{CO}_{2}$-driven ocean acidification on the early developmental stages of invertebrates. Mar Ecol Prog Ser 373:275-284

Lough JM (2008) Coral calcification from skeletal records revisited. Mar Ecol Prog Ser 373:257-264

Orr JC, Pantoja S, Pörtner HO (2005a) Introduction to special section: The ocean in a high- $\mathrm{CO}_{2}$ world. J Geophys Res 110, C09S01, doi:10.1029/2005JC003086

Orr JC, Fabry VJ, Aumont O, Bopp L and others (2005b) Anthropogenic ocean acidification over the twenty-first century and its impacts on calcifying organisms. Nature 437:681-686

> Pörtner HO (2008) Ecosystem effects of ocean acidification in times of ocean warming: a physiologist's view. Mar Ecol Prog Ser 373:203-217

Rost B, Zondervan I, Wolf-Gladrow D (2008) Sensitivity of phytoplankton to future changes in ocean carbonate chemistry: current knowledge, contradictions and research directions. Mar Ecol Prog Ser 373:227-237

Royal Society (2005) Ocean acidification due to increasing atmospheric carbon dioxide. Policy Document 12/05. The Clyvedon Press, Cardiff 